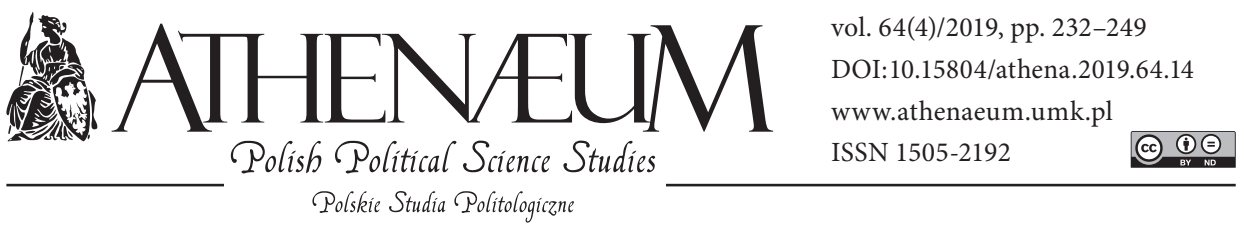

\title{
PUBLIC DIPLOMACY AS TAIWANESE DIPLOMACY'S ESSENTIAL TOOL
}

\author{
DYPLOMACJA PUBLICZNA JAKO ISTOTNE NARZĘDZIE \\ TAJWAŃSKIEJ DYPLOMACJI
}

Robert Rajczyk* ๑), Grażyna Piechota** 우

\begin{abstract}
The working paper consists of the analyses of different forms of Taiwanese public diplomacy and it also contains a future development scenario as far as such an essential tool of foreign affairs is concerned. The research project has been conducted from many points of view. There are institutional, strategic and operational dimensions of public diplomacy with the engagement of government officials and agencies, NGOs, public institutions and citizens as well. Having analysed the whole activity concerning public diplomacy, the main conclusion ought to be made, i.e., the official development assistance and humanitarian aid shall be provided as the most effective tool to enhance Taiwanese international visibility.
\end{abstract}

Keywords: public diplomacy; Taiwan; Republic of China; NGOs; IGOs
Artykuł prezentuje wynik analiz dotyczących różnych form dyplomacji publicznej prowadzonej przez Republikę Chińską na Tajwanie oraz możliwości rozwoju tego procesu. W toku badań wyróżniono trzy poziomy analityczne: strategiczny, instytucjonalny i operacyjny, obejmujące aktorów publicznych i niepublicznych zaangażowanych w realizację dyplomacji publicznej. Pomoc rozwojowa oraz pomoc humanitarna stanowią w przypadku Tajwanu najistotniejszy czynnik wzmacniania obecności Republiki Chińskiej na arenie międzynarodowej.

Słowa kluczowe: dyplomacja publiczna; Tajwan; Republika Chińska; NGO; IGO

* University of Silesia in Katowice, Faculty of Social Sciences.

** Andrzej Frycz Modrzewski Krakow University, Faculty of Management and Social Communication. 


\section{INTRODUCTION}

The analysis of Taiwanese Public Diplomacy's role in Taiwan's foreign affairs and its efficiency is the core idea of this working paper. That is why another purpose is to determine the main problems and obstacles of Taiwanese Public Diplomacy in order to discover the possibilities of resolving them and try to forecast the future development in correlation with the international legal status of the Republic of China (hereinafter known as the ROC).

The Republic of China is officially not recognized as an independent state within the UN system. According to the authorities in Beijing, Taiwan is a rebellious province of the People's Republic of China (hereinafter known as the PRC), whereas following the 1992 Consensus both countries have accepted the One China idea. The latter means that there is only One China but the PRC and the ROC identify themselves as China. It stands for the important issue in international relations. The common official recognition of the PRC and the ROC is accepted neither by Beijing nor Taipei. The One China policy has been supported by the political doctrine of "One Country Two Systems". It might be described as a concept of coexistence of socialism in mainland China and capitalism in Hong Kong, Macau, and Taiwan. Nevertheless, the ROC has been existing as a de facto state.

In 1945, the Republic of China has become the founding member of the United Nations and one of the permanent members of the Security Council. Because of the world's geopolitical situation and confrontation between the Soviet Union and its allies versus the Western democracies Taiwan withdrew from the United Nations upon the UN General Assembly Resolution 2758 dated 25 October 1971. Since then there have been several attempts to join the UN supported by Taiwan's allies. The Republic of China has diplomatic relations with eighteen countries in the world, including the Holy See in Europe and: Kiribati, Marshal Islands, Nauru, Solomon, Tuvalu, Belize, Dominican, El Salvador, Guatemala, Haiti, Honduras, Nicaragua, Panama, Paraguay, Saint Christopher and Nevis, Saint Lucia, Saint Vincent, Burkina Faso, and Swaziland (Eswatini). The relations with the other countries of the world are designed as cultural and economic ones. Due to that, Taiwan is one of the main actors of international affairs both in governmental and non-governmental international organizations ${ }^{1}$.

1 Taiwan has full membership in 37 intergovernmental organizations and their subsidiary bodies. It also enjoys observer or other statuses in 21 IGOs and their subsidiary bodies. 
ROC is a member of several international organizations such as WTO or Asia Development Bank. „Republic of China is a member of those organizations usually as Chinese Taipei or Separate Customs Territory of Taiwan, Penghu, Kinmen, and Matsu. The Asian Development Bank is the only exception. Republic of China is designated there as 'Taipei, China'. It might be misinterpreted as belonging to China whereas 'Chinese Taipei' is related to the Chinese culture" (Rajczyk, 2016, p. 75). In other international organizations Taiwan has the status of an observer, i.e., the World Health Assembly of the World Health Organization.

The system of exchanging information - the global information system plays the key role in the modern world. The country's position in the global market or geopolitical relations depends not only on the economic potential that is depicted by the competitiveness of the country but is also based on the national brand and national image. Nowadays, during the era of mass communication and post-information revolution period described by the enormous development of social and content media, an e-image is much more important than at any time earlier. Different tools such as mass media or soft power are triggering this phenomenon. The latter is done by many subjects of international affairs, e.g., states, countries, international organizations, either governmental or non-governmental, and citizens.

Public Diplomacy is “one of soft power's key instruments, and this was recognized in diplomatic practice long before the contemporary debate on public diplomacy" (Melissen, 2005, p. 4). According to Paul Sharp, Public Diplomacy is "the process by which direct relations with people in a country are pursued to advance the interests and extend the values of those being represented". Hans Tuch defined that as "a government's process of communicating with foreign publics in an attempt to bring about understanding for its nation's ideas and ideals, its institutions and culture, as well as its national goals and policies" (Tuch, 1990, p. 3).

In this working paper, Public Diplomacy shall be defined as a way of soft power that gives the state an opportunity to influence as well as to shape the world wide public opinion and helps to build a desired image of the country.

\section{RESEARCH'S METHODOLOGY}

The working paper will cover the hypothesis: the specific international status of Taiwan determines the tools that Taiwan uses in its Public Diplomacy. Therefore, there are research questions as follows: 
- How is Taiwan's Public Diplomacy conducted? What are the subjects of Taiwanese Public Diplomacy?

- What methods and techniques are used?

The survey shall obtain the Taiwanese authorities' reactivity to the important events and phenomena in the world, e.g., the Summer Universiade 2017 in Taipei and its impact on the global image of the Republic of China and its international recognition, as well as the interconnection between those issues and the activity as far as Public Diplomacy is concerned.

As an introduction to the project, an important division shall be made. The composition of Public Diplomacy consists of many sub-disciplines such as: cultural, economic, scientific or digital diplomacy. The studies will cover only the English content.

\section{PUBLIC DIPLOMACY INSTITUTIONS}

The ROC's Public Diplomacy shall be considered in its three aspects: institutional, strategic, and operational. The first one depends on the Constitution of the Republic of China. According to this document, the President of the Republic of China is the Chief of State and he or she represents the Republic of China in foreign relations. The Executive Yuan plays a role of the government with the Prime Minister as a leader, whereas the Legislative Yuan is the parliament. The government takes efforts in Public Affairs while the parliament develops the congressional diplomacy. There are the Department of Information Services, the Department of Information Management and the Department of Public Relations in the structure of the Executive Yuan. As far as the institutional aspect is concerned, the Ministry of Foreign Affairs shall be mentioned here. The MOFA maintains diplomatic relations with eighteen states throughout the world as well as with the rest of the world in the formula of international relations: economic and cultural. The Institute of Diplomacy and International Affairs is supervised by the MOFA. As far as Public Diplomacy is concerned, the IDIA provides workshops concerning that subject. Moreover, there are also Public Diplomacy Coordination Council and the Department of International Information Services. Both institutions' tasks include well-planned centrally coordinated Public Diplomacy agenda, e.g., e-diplomacy or foreign media service. One of the Deputy Ministers of the Ministry of Foreign Affairs supervises those two institutional bodies. 
National branding is one of the important issues related to Public Diplomacy efforts. There is the Taiwan Tourist Bureau in the structure of the Ministry of Transport and Communication responsible for the touristic promotion of the Republic of China. Nevertheless, according to President Tsai's inaugural address, the economic development is one of the most important issues for the government. The Bureau of Foreign Trade of the Ministry of Economic Affairs has been responsible for the foreign trade promotion.

Radio Taiwan International is another institution that could be involved in Public Diplomacy's activity. It broadcasts its programs in 13 languages providing the latest news from Taiwan to the listeners throughout the world and bringing the Taiwanese point of view on global issues to the audiences abroad.

The activity on the institutional level is state-subordinated due to all the above-mentioned institutions' subjection to the government or having the status of a public institution.

The non-governmental activity is the second aspect which enhances Taiwan's international visibility. For instance, it is the humanitarian aid conducted, among others, by Taiwan International Health Action or other NGOs and non-profit organizations such as TAITRA or Tzu-Chi, Taiwan's largest Buddhist charity.

Non-governmental organizations in Taiwan have been dynamically developing since the end of the martial law. Bonnie S. Glaser in her considerations devoted to the Taiwanese civil society emphasizes that: "Since martial law was lifted in 1987 and movement toward democratization made in the 1990s, Taiwan's domestic and international NGO participation has flourished. Today Taiwan has over 40,000 NGOs, some 2,100 of which operate internationally. Many of Taiwan's nongovernmental representatives are warmly received abroad, especially in humanitarian assistance, disaster relief, health aid, and environmental activities. This has provided Taiwan a degree of access to organizations and countries it otherwise would be denied" (Glaser, 2013, p. 29).

The development of civil society in the Republic of China has been politically supported since the turn of the $1980^{\text {s }}$ and the 1990s, seeing in the organizations' activity not only the possibility of enhancing governance as a system of managing public affairs on the national ground but seeing in the subject of organizations' activity and their international presence chances to achieve image objectives engraving in the consciousness of the international community that ROC is the only democratic China. Moreover, perceiving their role as actors supporting the subjectivity of Taiwan in international relations and thus the chance for public diplomacy. 
The International Cooperation and Development Fund of Taiwan should be mentioned here as a unique example. It is an independent organization with the status of a consortium of juridical persons. It develops agricultural, educational, environment, public health and medicine, information and communication technology's themes with the MOFA's cooperation that has commissioned some funds.

The Ministry of Foreign Affairs (MOFA), since 2000 creating the committee for non-governmental organizations, has undertaken effective attempts to globalize the perspective of activity carried out by the Taiwanese NGOs, thus assuming their use in public diplomacy. Taiwan has been engaged in projects aligned with the UN Millennium Development Goals (MDGs) such as: international humanitarian aid and medical assistance, eradicating poverty and disease, promoting democracy and human rights, and environmental sustainability. Activities undertaken by the MOFA concern both the support for Taiwanese organizations and starting cooperation with global non-governmental organizations and also carrying out educational activities making it possible for the employees of administration, the third sector, schools and students to increase their ability to participate in international affairs and extend international perspectives of their activity. Currently in the world there are almost 400 active Taiwanese organizations.

The activities of Taiwanese non-governmental organizations on a global scale are concentrated around two main issues. The first one is promoting democracy and human rights and support for and cooperation with global NGOs, what politically situates Taiwan (and lets it be perceived in this way) as the only democratic China. In Taiwan, international meetings and conferences devoted to NGOs and INGOs take place. Also offices are opened by global NGOs such as Reporters Sans Frontiers that protect democracy, freedom and human rights, what is a clear signal to acknowledge Taiwan as a country where such values are followed. Another area are actions aimed at the international community as an example of building "people-to-people diplomacy", which is based on organizing humanitarian aid for countries that are in need, taking part in removing the effects of disasters and also medical, developmental and environmental aid. This aspect of mainly aiding and humanitarian and development activities is aimed at building the awareness and enhancing the positive image of Taiwan directly among the beneficiaries of the Taiwanese NGOs.

As Bonnie S. Glaser (2013) points out: "Greater NGO participation has increased Taiwan's international profile and provided an avenue for Taiwan 
to interact with states around the world in a cooperative fashion. Taiwan's international NGOs have also enabled the island to engage in unofficial forms of international and people-to-people diplomacy, which has promoted better relations with countries both in the Asia-Pacific region and around the world" (Glaser, 2013, pp. 30).

Both spheres of NGOs' activity in the international arena are thus concentrated on the activities that should be treated as soft power activities - image enhancement, promoting positive message about a country, as well as establishing relationships between societies and building trust in the national brand. According to Steve Tsang (2008): “[T] he soft power [is] inherent in Taiwan`s impressive democratization, and [this is] one way of asserting influence that the ROC government used effectively for decades even before the advent of real democracy in Taiwan. [...] Indeed, considering its inability to gain international recognition or membership of the $\mathrm{UN}$, and given that its need to defend itself against China completely absorbs its considerable military capabilities, soft power is of greater importance to Taiwan that to any other country" (Tsang, 2008, pp. 9-10). Kelly Gerard (2014) claims that the role of civil society organizations is growing thanks to including civic institutions into political processes: "Regional and global governance institutions have increasingly included Civil Society Organizations in policymaking. Scholars have documented this trend, highlighting its growing prevalence and limitations. [...] It also highlights the vast spectrum of mechanisms for civil society participation that exists across institutions, and the subsequent differing abilities of CSOs to influence policy and shape political outcomes" (Gerard, 2014, pp. 173-174). Non-governmental organizations as the ones active outside government relations but serving political functions have become an actor thanks to which participation of Taiwan in international relations is possible. This is emphasized by Gary D. Rawnsley (2014), writing: "Public diplomacy from civil society and among NGOs can be considered a by-product of a nation's soft power because their work reflects a democratic culture that encourages pluralism, diversity and charity. They are also largely immune from changes in ruling parties and their ideological positions. For this reason, Taiwan's civil society offers soft power advantages over the PRC where the government manages the non-governmental sector, and therefore lacks the kind of credibility that would make it an agent of soft power. Moreover, the non-governmental sector is able to forge and sustain meaningful long-term relationships with groups and individuals overseas" (Rawnsley, 2014, p. 164). As Wen-Jong Juang (2015) analyzing the political role of Taiwanese NGOs remarks, 
their role will be rising: "As NGOs become increasingly professional and independent with enhanced capabilities for policy analysis they will be considered as taking a dominant and representative role on certain issues. This recognition will facilitate the promotion of their preferred policy solutions and as a result the goals of the organization will be accomplished" (Wen-Jong, 2015, p. 166).

Another important factor achieved through the inclusion of media in providing information devoted to the activity of Taiwanese non-governmental organizations is the narration of the history of Taiwan, which emphasizes the shift from authoritarian rule to representative democracy. Democracy and its values have become an actual Taiwan's export commodity.

Activity of the Taiwanese civil society which has become the promotor of Chinese democracy leading to polarization of the ROC and the PRC in the reception of the international community is also used in the soft power for the benefit of conducting politics in Taiwan, limiting the influence of mainland China on the internal policy of the ROC.

As far as the strategic dimension is concerned, steadfast diplomacy is the key issue of the presidency of Tsai Ing-wen (term 2016-2020)2. The full international recognition of the Republic of China is one of its key political issues. That agenda also refers to the content of the strategic communication. The analysis of the content of websites and profiles in social media of the President, the Executive Yuan, and the Ministry of Foreign Affairs, has revealed that Taiwanese authorities are focused mainly on improving the economic potential of the Republic of China using the social media. Nowadays, the Tsai's administration social and content media is a platform for real communication as it was during the electoral campaign in 2015. It refers to the WHA's issue. Because of the opposition of the People's Republic of China, Taiwan was excluded from the annual meeting of the WHA. The President's reaction was expressed on Twitter several times in different languages, including English, in order to gain as much coverage in social media as possible.

The dilemma of the international status of Taiwan and its correlation with the foreign policy and communication efforts is a key issue here. Flexible or

2 Steadfast diplomacy is Tsai's political concept which aims to "advance mutual assistance for mutual benefits. The policy is also defined as firm in purpose and is targeted at building robust relationships with diplomatic allies and countries that share the common values of freedom and democracy. Under this approach, the focus of the country's diplomatic work is shifting from the one-way provision of foreign aid to two-way dialogue, with bilateral cooperation projects taking into consideration the development of both industries and markets" (Forreign Affairs, 2018). 
viable diplomacy initiated in 1993 is the main way of conducting the Taiwanese diplomacy (Yahuda, 1996, p. 285). It means that efforts are focused on improving the economic potential and the presence in the international community. The latter could be described as a "southward policy" which means "a desire to avoid becoming excessively dependent upon economic ties with the mainland", whereas the steadfast diplomacy might be considered as a step to gain the full international recognition of the ROC (Yahuda, 1996, p. 290).

As far as the foreign policy agenda is concerned, the Minister of Foreign Affairs is reporting the agenda's purposes regularly to the Legislative Yuan. Public Diplomacy is developed in these documents, i.e., the role of Taiwanese NGOs in international humanitarian affairs and creating the positive image of the ROC.

Continuing to promote participation in international organizations through pragmatic approaches is supposed to be one of the most important purposes of Taiwanese foreign policy. Due to that, Taiwan is able to function and coexist in the international community, e.g., in international aviation, maritime transport or navigation, etc.

\section{EXECUTIVE DIMENSION OF PUBLIC DIPLOMACY}

The operational aspect of public diplomacy brings the analysis of different projects implemented by many institutional subjects as well as citizens.

The type of public diplomacy refers to the tool that has been used. So the Public Diplomacy consists of, e.g.: cultural diplomacy, economic diplomacy, NGO diplomacy, scientific diplomacy, citizen diplomacy, digital diplomacy, Public Affairs, as well as national branding or event marketing. The latter helps to build the national brand especially due to, e.g., international sport events. Moreover, event marketing, or sport diplomacy ought to be mentioned. There is a tight correlation between national branding and the signification of international events such as Universiade, for example. The 2017 Summer Universiade gives the Taiwanese authorities a brilliant possibility to promote Formosa (the old name for Taiwan) as a touristic destination both for the academic sports fans as well as for the academic athletes. Because of Taiwan's unique status in international affairs, Taiwanese competitors attended the Universiade under the name of "Chinese Taipei". The differentiation between Taiwan, the Republic of China, and "Chinese Taipei" is important for increasing the country's brand awareness. It might also be a way to influence the international community to 
persuade the discussion about Taiwan's status in international affairs. Besides official promotion about the Universiade, there were many examples of guerrilla marketing, such as transforming Taipei's metro into a "swimming pool". The event was widely open for the public. The tickets, for instance, were available in every shop via payment machines.

As far as the issue of Taiwan as a tourist destination is concerned, the content of mass media and social media about Universiade has been prepared in a professional way. It contains layout that is easy to navigate and is friendly to users. What is more, there are plenty of useful pieces of information designed for the fans or tourists. Tourism is supposed to become an important part of the state's economy, that is why the touristic promotion is a key issue in Public Diplomacy due to its connection with people-to-people relations, which help to build the image of the national brand. The latter could also be valuable ${ }^{3}$.

Nowadays, selling emotions is the key to persuade tourists to come and visit a destination. So the storytelling about a place plays a significant role. Although historical monuments and buildings are also important but without the plot, the promotion is not as effective as it could be with the storytelling. The dilemma is how to attract the desired audience. Nowadays, the Internet is supposed to be the main source of information. It means that the role of recommendation and sharing the opinion of Internet users is much more reliable than any other slogans or leaflets. Besides the emotions, the desired audience ought to be reached in its typical information milieu. The Taiwan Tourist Bureau has several websites dedicated to different aspects of Internet communication. Profiling the content towards the desired audience is a key issue that guarantees the success in that process. Each of the websites emblems the unique approach of publicity and symbolizes the trends in modern communication, e.g., Trending Taiwan is a tool of digital diplomacy or a website designed as a platform to find an interesting event (www.eventaiwan.tw) - an example of event marketing and place marketing. Trending Taiwan features captivating videos and information which introduce diverse and intriguing aspects of the Republic of China (Taiwan). The international visibility and the Taiwanese contribution or participation in the international community is also under consideration during the analysis of Trending Taiwan.

3 Taiwan's nation brand value is estimated at 469 billion USD, according to the Nation Brands 2016. The Annual Report on the World's Most Valuable Nation Brands (2017). 
The core idea of Taiwan's touristic promotion is coherent with the content. The slogans such as: "Taiwan. Touch Your Heart", "Time for Taiwan - Time for Celebration”, or “Time for Taiwan”, “Anytime for Taiwan”, and “Taiwan. The Heart of Asia", have been corresponding with users' interests and modern trends in communication. All those projects mentioned above concerned bringing the emotions to the participants. The content is managed with videos and photos. This trend of visualization correlates with the model of social or mass media coverage requirements. The webpage about Taiwan's tourism ambassador OhBear is also the example of this phenomenon and helps to sell Taiwan's tourist brand with the mascot. Besides, the fondness for mascots has been a social phenomenon throughout the East Asia, especially in Japan, Mainland China, or the Republic of China.

The storytelling and the wide use of the Internet are the most important tools of promotion nowadays. The digital diplomacy - the diplomacy via social and content media made by different subjects, either governmental or non-governmental, e.g., citizens - is a key instrument to communicate the ideas because of the social media popularity. After all, the results gained by the digital diplomacy efforts might be considered helpful in persuading the international public opinion that implies the possibility of changing the foreign governments' policy towards the host of digital diplomacy.

The national brand built by efficient communication influences the countryof-origin effect, which is extremely vital for the country's economy. There are many instruments to promote country's brands and products. International trade provides different possibilities, i.e., participation in international affairs due to the economic potential.

The promotion of the Taiwanese trade is done in many ways: as economic diplomacy on the one hand, or as corporate diplomacy on the other. There are a few projects concerning trade promotion abroad, e.g.: Taiwan Excellence, Trade Show or Taiwan Product Center, Global Government Procurement Project and trade missions or even the online catalogue of Taiwanese products.

The Taiwan External Trade Development Council (TAITRA) and the Bureau of Foreign Trade of the Ministry of Economic Affairs coordinate all of them. Furthermore, the Taiwan Excellence program is a project designed to support the Taiwanese products in order to build reliable relations with customers abroad based on the country-of-origin effect. For example, in July 2017 in Malaysia, which is believed to be one of the most efficient emerging markets, Taiwan Excellence in Kuala Lumpur Monorail - a unique means of transportation popular 
among tourists - organized the promotional campaign. Taiwan Industry Image Enhancement Project (IEP) is another example of enhancing the innovative image of Taiwanese industry. The project is targeting 15 countries. Taiwanese economic diplomacy is supposed to be treated as an effective one due to the position of Taiwan's economy in the global economic exchange as well as the image of Taiwanese brands mainly in the IT industry (HTC, ASUS) or bicycle industry, e.g., Giant, or Merida. Nonetheless, the efficiency of the country-of-origin effect is exercised by an image of the brand. In such a case, the corporate diplomacy plays a significant role because of the Corporate Social Responsibility's activities (Tang \& Li, 2011). Sometimes, corporate diplomacy merges cooperation between a state-owned promotion agency and private entrepreneurs. The example comes from Singapore where the campaign with the slogan "Rediscover Taiwan" was launched on billboards sponsored by the Taiwan Tourism Bureau accompanied with the promotional campaign of Taiwanese private airlines in July 2017.

Eventually, both tourist promotion and trade promotion are exercised via Internet due to its position in global network of communication. The emotions are sold in both cases. In the first one, the emotions are concerned with storytelling, in the other, with the product's Public Relations. It has been exercised through the new media, content media and social media as well. Usually, the state-owned television or radio channels exercise mass media diplomacy. In Taiwan, there is Radio Taiwan International, which broadcasts its program in several foreign languages and offers content via mobile applications in these languages in order to provide the listeners with a wide range of Taiwanese culture, history and society issues throughout the world. The Taiwan Broadcasting Service (TBS) is a public television consortium that consists of the Chinese Television System and the Public Television Service. The former began its history as a joint venture of two Taiwanese ministries. The latter is the first independent public broadcasting institution in Taiwan. It holds public television channels in Taiwan, does not offer the channel for diaspora or foreign audiences, media diplomacy is developed through satellite broadcasting or Internet streaming, for instance to Mainland China. What is more, Taiwanese media stand for the alternative and objective source of information for the Chinese compatriots living in Mainland China, Macau, and Hong Kong.

Cultural diplomacy is also related to media coverage. The content that has been broadcast via mass media to the audience abroad (foreigners or diaspora) involves promotion of the culture. Although there is no television channel designed for these viewers in Taiwan, some productions are distributed with 
the worldwide online streaming platform Netflix or due to the international co-production. International cultural exchange shall be mentioned and programs developed for foreigners on the spot such as "Mandarin On-the-Go" that is a Mandarin learning program which invites foreigners to learn about Taiwan's culture. They promote not only the Taiwanese culture but also Taiwan as a sovereign country raising the foreign audiences' awareness of the ROC and its successful existence in the international community.

As far as the culture is concerned, the religion is a part of it. The religion could be a link between the nations or people of the same confession. The example comes from Mainland China where for example Buddhism, a traditional religion, was revived due to the engagement of a religious foundation from Taiwan which had sponsored the process as well as the charity (Yun-han, 2011, pp. 127-130).

The charity activity also plays an important role in public diplomacy. Usually it has been exercised by private individuals - entrepreneurs - but mostly by the NGOs as NGO diplomacy. Humanitarian aid or charity networks provide the possibility to raise Taiwan's presence in the international community. These activities are politically neutral and provide Taiwan with a good image. The same situation appears with the development aid. Taiwan is a very active country in this field ${ }^{4}$.

Sport, culture and science are said to be non-political activities. They regard people-to-people relations during the individual contact. "The Youth Ambassadors" program shall be mentioned here. The Ministry of Foreign Affairs of the Republic of China launched it in 2009 to promote Taiwanese soft power and over 1400 students have been involved in it since its beginning. It shall be pointed out here that the Youth Ambassadors project is open especially for participants of non-Taiwanese ethnic origin. They are more efficient in communication and cooperation with people of similar ethnicity or compatriots abroad.

Citizen diplomacy is also endorsed by the volunteers who work and help to promote their country and shape its image abroad. There are: Taiwan Youth Overseas Service, and TaiwanICDF Overseas Volunteers Service, for example. Together with participants of the Youth Ambassadors project, the volunteers work on enhancing the awareness of Taiwanese sovereignty and Taiwan's unique status in international relations. That might influence public opinion. Then the people may persuade or motivate its own government to make some decisions concerning the enhancement of the ROC's presence in the international community.

4 See more about the Taiwanese humanitarian aid in: Passion and Care. 2000-2006: The Story of Taiwan's Global Health Humanitarian Aid (2007). 
Scientific diplomacy is yet another way to practice Public Diplomacy. It mainly consists of the students and academics' exchange programs that are usually sponsored by the state-based subjects, i.e., public institutions or NGOs. Scientific research symbolizes the freedom of demonstrating the plurality of thinking. Taiwan offers scholars a wide range of scholarships. The review of the list of recipients and topics of their projects shall be interpreted as an analysis of contemporary Taiwan and its achievements as well as its history, the role in international affairs, and is related to Taiwan's democracy or human rights because of Taiwan's status of being the only one Chinese democracy. The results of the international academics' research projects mean Taiwan's inclusion into the international academic mainstream. The international scientific exchange programs provide the opportunity to share Taiwanese history, culture and values throughout the wide audiences in different countries and to promote Taiwan as a tourist destination. The advertisement based on the personal recommendation is much more reliable than any other means of promotion so it is an excellent way to point out the Taiwanese brands or Taiwan as a sovereign state. The scientific diplomacy also has its practical dimension that might be important to solve the global issues such as global warming or natural disasters.

\section{INDIVIDUAL AND INSTITUTIONAL DIMENSIONS OF PUBLIC DIPLOMACY}

The Public Affairs' aim is to inform foreign governments or citizens publicly. It could be called information policy or propaganda. Besides the social or content media, it consists of, e.g., official publications. The "Taiwan Panorama", widely available in foreign Taiwan's offices around the world, or "Taiwan Today" and the "Republic of China. Yearbook" are the examples of shaping and framing Taiwan's image through the audiences outside Taiwan. Those periodicals are delivered to the readers in a few foreign languages. Their content covers regularly the most important events in Taiwan in politics, culture, sport, economy, society, and environment. All of these publications including "The Republic of China (Taiwan) at a Glance" are available on-line for free in popular foreign languages.

The Public Diplomacy Coordination Council and the Department of International Information Services in the Ministry of Foreign Affairs perform Public Affairs duties successfully. 
Although, Yun-han Chu notes that many "[...] of the island's social actors pursue their own political, social, and/or cultural agenda when they become involved in cross-Strait cultural exchange" (Yun-han, 2011, p. 121). That is why the strategy is important in making Public Diplomacy. So the key issue must be obviously set up. According to Taiwan's international status, it could be culture - the traditional Chinese one and modern Taiwanese - or the efficiency of democracy as a concept contrary to the People's Republic of China political regime. Due to that, more attention is being paid to Taiwan and its unique international status. Setting up culture and democracy as narratives helps to persuade audiences around the world to sympathize with the ROC.

According to Katarzyna Pisarska's parallel model, the Taiwanese public diplomacy might be classified as a constructive one. The constructive type of public diplomacy consists of:

- values and ideas as key actors,

- cooperation to redefine the international system as a key interest,

- power-sharing schemes of sources of power,

- contributing to the public global good,

- collaboration and networking as a mode of communication,

- humanitarian and development aid as a preferred instrument (Pisarska, 2016).

Effective public diplomacy requires legitimacy from the society. Pisarska stands for three aspects of public diplomacy's domestic outreach:

- identity - defining a platform in order to strengthen the nation,

- informative - explaining foreign policy to domestic publics,

- cooperative - engaging civil society in state Public Diplomacy and supporting independent NGO diplomacy.

Reconciliation could be the value to be developed for Public Diplomacy. It may help to frame news from Taiwan in the global mass media circulation. The DPP's administration promotes ethnic diversity of the country in an institutional way. There are: the National Day of Indigenous People on August 1st, the Hakka Affairs Council and the Council of Indigenous Peoples in the structure of the Executive Yuan as well as a nationwide radio station for them or even a television channel and virtual museum. Moreover, the ethnic history of Taiwan comes up as an issue in public debate as a tool to distinguish Taiwanese culture. It was shown to the world during the opening ceremony of the $29^{\text {th }}$ Summer Universiade in Taipei in 2017. 


\section{CONCLUDING REMARKS}

Despite the unique status in international affairs, the international visibility of the Republic of China is not questionable due to the efforts made by the government, civil society and citizens.

Public Diplomacy starts on the individual level due to the digital diplomacy that should be considered as the most effective one because of its reliability. Citizen diplomacy or NGOs' diplomacy shall be separated from the government's activities in order to maintain credibility.

But the cooperation and integration of efforts must be done on the domestic level. Bonnie S. Glaser recommends some issues to improve Taiwan's participation in the international NGOs such as continuing to block China's efforts to interfere in Taiwan's international presence as well as lobbing to expend Taiwanese participation in regional NGOs (Glaser, 2013, pp. 39-41). Glaser also notices that NGO participation abroad has benefited Taiwan but it has not been an effective substitute for official status in multilateral institutions (Glaser, 2013, p. 31).

According to the performed SWOT analysis presented below, the main Taiwanese public diplomacy's obstacles are of socio-economical nature and they also involve China's political pressure on the international community.

Table 1. Taiwanese Public Diplomacy SWOT Analysis

\begin{tabular}{|c|c|c|}
\hline & Positive & Negative \\
\hline Internal & $\begin{array}{l}\text { Strengths } \\
\text { - stable democracy } \\
\text { - ancient culture } \\
\text { - well-developed civil society } \\
\text { - innovation economy } \\
\text { - hi-tech } \\
\text { - hospitality (people-to-people diplomacy) } \\
\text { - fellowships } \\
\text { - NGOs' diplomacy }\end{array}$ & $\begin{array}{l}\text { Weaknesses } \\
\text { - low birth rate } \\
\text { - low economic growth } \\
\text { - unemployment } \\
\text { - brain drain }\end{array}$ \\
\hline External & $\begin{array}{l}\text { Opportunities } \\
\text { - expats: Contact Taiwan Program } \\
\text { - development assistance } \\
\text { - humanitarian aid } \\
\text { - working holidays program }\end{array}$ & $\begin{array}{l}\text { Threats } \\
\text { - unique international status } \\
\text { - instances of PRC's interferences }\end{array}$ \\
\hline
\end{tabular}

Source: authors' own elaboration. 
Public diplomacy is a tool to enhance relevance and prevent marginalization in the region and the world stage at large. Despite the predicament and due to the high level of economic growth, Taiwan is faced to be a vulnerable, reliable, responsible and significant member of the international community. The official development assistance and humanitarian aid shall be provided as the most effective tools in order to enhance Taiwan's international visibility. The specific international status of the ROC does not determine public diplomacy's activity. The content depends on state authorities' political agenda. Notwithstanding the political ideology, Taiwan's public diplomacy conducted by the government or public institutions subordinated to authorities is state-based and centrally coordinated. It means an unequivocal message and integrated efforts that ensure the efficiency and depict the ROC as a modern economy with a stable and liberal democracy. That is the core idea of Taiwanese public diplomacy supported by other non-state based actors (citizens, NGOs, etc.) who have been involved in the process of communication because the success in public diplomacy is not possible without the individual aspect in that process. It requires the civil society's involvement. The acceptance of the society is the crucial issue in Public Diplomacy's achievements. Nowadays, it is a trend to facilitate the value of soft power for East Asian countries (Lee \& Melissen, 2011, p. 8).

\section{ReFERENCES:}

Forreign Affairs (2018). Retrieved from: https://www.taiwan.gov.tw/content_5.php [access date: 28.01.2019].

Gerard, K. (2014). ASEAN's Engagement of Civil Society: Regulating Dissent. New York: Palgrave MacMillan.

Glaser, B.S. (2013). Taiwan's Quest for Greater Participation in the International Community. Lanham: Rowman \& Littlefield.

Lee, S.J., \& Melissen, J. (eds.). (2011). Public Diplomacy and Soft Power in East Asia. New York: Palgrave Macmillan.

Melissen, J. (ed.). (2005). The New Public Diplomacy: Soft Power in International Relations. New York: Palgrave Macmillan.

Nation Brands 2016 (2017). The Annual Report on the World's Most Valuable Nation Brands. Retrieved from: http://brandfinance.com/knowledge-centre/reports/brandfinance-nation-brands-2016/.

Passion and Care. 2000-2006: The Story of Taiwan's Global Health Humanitarian Aid (2007). Taiwan International Health Action (Taiwan IHA). Retrieved from: http://www.mofa.gov.tw/Upload/RelFile/1227/4541/c2d7e4f0-90eb-4d21-a203ac6377b8b20a . 
Pisarska, K. (2016). The Domestic Dimension of Public Diplomacy: Evaluating Success through Civil Engagement. London: Palgrave Macmillan.

Rajczyk, R. (2016). World's Impact on the Taiwanese Media System. China Media Research, 12(3), 74-80.

Rawnsley, G. (2014). Taiwan's Soft Power and Public Diplomacy. Journal of Current Chinese Affairs, 43(3), 161-174. DOI: 10.1177/186810261404300307.

Tang, J., \& Lee, H. (2011). Chinese Corporate Diplomacy: Huawei's CSR Discourse in Africa. In: J. Wang (ed.). Soft Power in China (pp. 95-115). New York: Palgrave Macmillan.

Tsang, S. (2008). Taiwan as a Member of the International Community. In: S. Tsang (ed.). Taiwan and the International Community (pp. 8-21). Bern: Peter Lang.

Tuch, H.N. (1990). Communicating with the World: U.S. Public Diplomacy Overseas. New York: St. Martin's Press.

Wen-Jong, J. (2015). Policy Analysis by Non-governmental Organisations in Taiwan. In: K. Yu-Ying (ed.). Policy Analysis in Taiwan (pp. 152-168). Bristol: Bristol University Press.

Yahuda, M. (1996). The International Standing of the Republic of China on Taiwan. China Quarterly, 148, 1319-1339. DOI: 10.1017/S0305741000050645.

Yun-han, C. (2011). Taiwan's Soft Power and the Future of Cross-Strait Relations: Can the Tail Wag the Dog? In: S. Jong Lee, \& J. Melissen (eds.). Public Diplomacy and Soft Power in East Asia (pp. 117-137). New York: Palgrave Macmillan. 